\title{
Local Government Asset Management: Affecting Factors and Policy Implications on Government Work Unit of Central Java Province in Indonesia
}

\author{
Gregorius Nasiansenus Masdjojo, Ratna Sri Kumala Dewi \\ Universitas Stikubank, Semarang, Indonesia
}

\begin{abstract}
This study aims to analyze the influence of Human Resource Competence, Regulation, Information Technology, Reconciliation, and Internal Control System on Asset Management in Local Government Work Unit (abbreviated SKPD) of Central Java Provincial Government. This research is conducted because there is still record in the Final Report of Inspection by the Republic of Indonesia Audit Board (abbreviated BPK) concerning problem of asset management conducted by some SKPDs of Central Java Provincial Government, although in general the Local Government Financial Report of Central Java Province has got opinion “Reasonable Without Exception”. The data source of this research is primary data collected through interview method on asset management officers at the 48 SKPD in Central Java Provincial Government. Data analysis method used in this research is multiple regression analysis. This research finds that the Human Resource Competence, the Regulation, the Information Technology, the Reconciliation, and the Internal Control System have positive and significant effect on the Asset Management at the Local Government Work Unit of Central Java Provincial Government at level of significance 0.05. Ability to explain of the independent variables to the Asset Management variable is equal to $67.7 \%$.
\end{abstract}

Keywords: assets management, competence of human resources, regulation, information technology, reconciliation, and internal control systems

\section{Preliminary}

The implementation of regional autonomy in Indonesia under the law No. 32 of 2004, increasing consequences of local government authority as a result of the delegation of the affairs was originally done by the central government which is then transferred to the regions. One of them is the change of authority in the management of government assets which was originally mostly handled by the central government. By implementation of the regional autonomy, local governments will receive greater authority to manage their assets. Regional autonomy also had an impact on the demand for public accountability and transparancy in the development process of local government management in Indonesia in order to create clean and good

Gregorius Nasiansenus Masdjojo, Dr., MKom, M.Si., lecturer, Faculty of Economic and Business, Universitas Stikubank, Semarang, Indonesia.

Ratna Sri Kumala Dewi, S.E., M.M., post graduate student, Post Graduate Program, Universitas Stikubank, Semarang, Indonesia.

Correspondence concerning this article should be addressed to Gregorius Nasiansenus Masdjojo, Faculty of Economic and Business, Universitas Stikubank, Jl. Kendeng V, Bendan Ngisor, Semarang, Indonesia. 
governance (Azhar, 2007).

Law Number 17 of Year 2003 on State Finance Article 1 paragraph 1 states that the State Finance is all rights and obligations of which can be measured by money, and everything in cash, as well as everything in cash or in the form of goods that can be owned by the State in connection with the implementation of rights and obligations. This means that the management of goods can not be separated from financial management.

Given the importance of asset management for the government as well as the amount of expenditures States with regard to the management of these assets, it has become imperative for the government to conduct asset management/state property in a professional, effective, and forward the economic aspects that expenses are right on target, right use, right implementation, and in accordance to legislation in force.

Asset management is actually an integral part of the financial management and is generally associated with the administration of regional development, especially with regard to the value of assets, asset utilization, recording the value of assets in the balance sheet, as well as in the preparation of the priorities in development (Oates, 1995).

Adequate asset management should include the procurement of assets, transferring assets, asset inventory, asset accounting management information systems and accounting sectoral asset, and the preparation of financial statements (Abdullah, Razak, \& Pakir, 2011). If all goes well, the process concerning the assets of regional information will be accurate and avoid financial statements disclaimer of opinion (Von Hagen, 2002). Weaknesses that should be corrected is related to weakness associated with assets that can affect CPC opinion among others, yet all the working unit inventory and revaluing its fixed assets. Another factor that needs to be improved is the recording of assets only from capital expenditure for the year so that the assets derived from capital expenditure of the previous year are not accumulated reported, the beginning balance of fixed assets on the balance sheet has not been adjusted for the ending balance audit the previous year so that the final balance sheet after coupled with a mutation of the current year end still displays the data error (Azhar \& Darwanis, 2013).

Although the Local Government Finance Report of Central Java province gets an unqualified opinion for three consecutive years, the problem of asset appears as an expslanatory paragraph in the opinion for the examination of the fiscal year 2013 and fiscal year 2014. The audit report of the audit board of the Republic Indonesia RI Representative of Central Java Province No. 35A/LHP /BPK/XVIII.SMG/05/2014 Date May 10, 2014 states that land fixed assets are recorded in the balance sheet as of December 31, 2013 by Rp12,05 trillion, there is still a land asset for roads and irrigation which is proof of ownership on behalf of the central government that needs to be validated to ensure the existence and rights of possession. While the audit report of the audit board of the Republic Indonesia RI Representative of Central Java Province No. 35A/LHP/CPC/XVIII.SMG/06/2015 Date June 16, 2015 states that the status of land ownership that has not been validated by the provincial government of the central government and district/city implications for road and bridge assets which are located on the ground also require validation before accounting policy for depreciation is applied.

Based on the above, it is interesting for further study on asset management in the Central Java Provincial Government and the factors that influence it. This research is important to improve asset management in the Central Java Provincial Government. The improvement in asset management of the working unit expected financial reports of Central Java Provincial Government retains the unqualified opinion. 


\section{Theoretical Framework}

\section{The Definition of Regional Asset Management}

Assets according to Goverment Regulation No. 71 of Year 2010 concerning the Government Accounting Standards are economic resources controlled and/or owned by the government as a result of previous events and from which the benefits of economic and/or social in the future are expected to be obtained, both by governments and society, and can be measured in terms of money, including non-financial resources necessary for the provision of services for the public and resources are maintained for historical reasons and culture. The Goverment Regulation No. 71 of Year 2010 classifies assets into fixed assets and other assets.

Asset management is the process of managing assets (wealth), both tangible and intangible that has economic value, commercial value, and the exchange rate, to encourage the attainment of the objectives of individuals and organizations. The process of management assets aims to make a profit and to reduce cost efficiently and effectively (Hanis, Trigunarsyah, \& Susilawati, 2011).

Asset Management Area is implementing asset management/regional property based on the principle of the basics of asset management to asset by following a policy platform which is governed by the act, government regulations, presidential decrees, ministerial decrees, and decree related to arrangements/asset management area (Wong, 2004).

\section{Factors Affecting the Regional Asset Management}

According to Liu (2000), there are five purposes of asset management, namely: the clarity of the ownership status of assets, inventory of area properties and lifetime of assets, optimization of the use and utilization to increase revenues where assets status as idle capacity can be utilized according to the designations assigned, in addition optimized asset utilization can identify and can recognize purpose of those assets, can be intended for anyone and can bring in revenue for asset managers if they can manage assets in accordance with applicable rules, assets management, and basic preparation of trial balance. Factors affecting asset management can not be separated from the elements involved in asset management and author of the report property area.

Based on the flow and the elements of the implementation of asset management, there are five main factors that determine the quality of the effectiveness of the asset management area, namely: (1) Competence of human resources; (2) Regulation; (3) Information technology used; (4) The intensity of reconciliation; and (5) Internal control systems.

\section{Competence of Human Resources}

Hanis et al. (2011) described the competence of human resources is the human resource capacity to perform the tasks and responsibilities assigned to him with sufficient provision of education, training, and experience.

\section{Regulation}

Regulation is a provision which is used to regulate human relationships in a society or a country . Article 1 paragraph 2 of Law No. 12/2011 on the establishment regulations stated that the legislation was written regulations containing binding legal norms in general and established or designated by the institution or the competent authority via procedures specified in legislation. Regional governments should set itself the management of assets (Article 1 of Law No. 32/2004). 
In the context of decentralization, local goverments are given the authority to make its own legislation, which must not conflict with higher laws (Article 1 paragraph 5 of Law No. 32/2004). Central Java Provincial Government set Central Java Governor Regulation No. 96 Year 2012 on regional property management guidelines as the basis for the implementation of asset management. Another rule also used as a reference in the area of administration of assets is the Governor Regulation No. 45 of Year 2014 concerning policy and accounting system of Central Java Province with respect to recognition, measurement, and presentation of the assets in the balance sheet.

\section{Information Technology}

Technology is a tool that is used by individuals in the completion of their tasks (Goodhue \& Thompson, 1995). In the context of information systems, technologies related to computer systems (hardware, software, and data) and the use of support services (training, for example) give the user guide to complete the tasks. The model focused on the influence of specific or general effects of a set of systems, policies, and services rendered by the department of information systems.

In 2013, Central Java Provincial Government in cooperation with SeML System Development Information System and Asset Management (SIM Asset) developed a system of open time or open when there are changes in the basic regulations in implementation. SIM Assets Application refers to the logistic cycle management of regional goods in accordance with the regulations of Ministry of Internal Affairs No. 17 of 2007. System applications are built on line with the method 2 (two) tier which is the client (user) directly related to the database server by using the Internet network (user online ) and use the local device through a switch hub (local user). Static IP (Internet Protocol) uses the speedy network owned by Telkom as a destination or address database where data are collected centrally.

\section{Reconciliation}

In accordance, Director General of Treasury Regulation No. PER/PB/2009 on Guidelines for Preparation of Financial Statements Reconciliation and Attorney General Treasurer, reconciliation is one of the keys in an effort preparing financial statements credible. This is due to the role that is important in order to minimize the occurrence of differences in recording the impact on the validity and accuracy of the data presented in the financial statements

Reconciliation is done in the framework of the management of the assets in Central Java Provincial Government aiming to obtain the correct value of the assets and valid. Implementation of reconciliation is divided into several stages (Pradono, 2014):

(1) Reconciliation between board items by preparers of financial statements of the working unit;

(2) Reconciliation between board items and a rapporteur with DPPAD, coordinator of the local asset manager in Central Java Provincial Government;

(3) Reconciliation between board items and preparers of financial statements with the accounting section finance bureau as the authors of the report on the financial Central Java Provincial Government;

(4) Reconciliation between DPPAD with the accounting section finance bureau as the authors of the report on the financial Central Java Provincial Government.

\section{Internal Control System}

Government Regulation Number 60 of 2008 defines the Internal Control System of Government is a process that is integral to the actions and activities carried out continuously by the management and all 
employees to provide reasonable assurance on the achievement of organizational goals through effective and efficient activities, the reliability of financial reporting, security state assets, and compliance with laws and regulations. SPI is control activities mainly on the management information system that aims to ensure the accuracy and completeness of information

\section{The Relationship of Competence of Human Resources With Asset Management}

With the existence of competent human resources and a good understanding about the asset management area, it is expected that a report on education can present a valid asset. Empirical evidence of the influence of human resource competencies in the management of the assets found by by Darno (2012) and Hanis et al. (2011) showed that the ability of human resources has positive effect on the quality of goods report and reports quality regional assets. Based on the concepts and empirical evidence obtained from previous studies, the hypothesis 1 is proposed:

H1: Competence of human resources had positive effects on asset management.

\section{The Relationship of Regulation and Asset Management.}

To meet the needs of the public on good legislation, it needs to make regulations regarding the establishment of legislation that is implemented in the manner and certain and established method, and standards that bind all competent institutions form of legislation ( in the weighing of Law No. 12/2011). In the hierarchy of legislation, laws in force in the area consist of local legislation, regulation, or decision region head and head area.

The influence of regulation on the assets management found by Iqlima showed that each $100 \%$ increase in regulation, then in relative terms will also be a positive influence on asset management significantly. Based on the concepts and empirical evidence obtained from previous research, hypotheses 2 is proposed:

H2: Regulatory had positive effects on asset management.

\section{The Relationship of Information Technology With Asset Management}

Utilization of information technology that includes computer technology and communication technology in the management of finances and assets is going to improve the processing of transactions and other data, the accuracy in the calculation, as well as the preparation of reports and other outputs in more timely manner. Use of information technology will also help speed up the process of transaction data processing and presentation of financial statements and assets which are government so that the financial statements and the assets of the area do not lose the value of information, namely prudency.

Research of Azhar (2013) showed that the use of information technology has a significant effect in line with the research of Hanis et al. (2011) who stated that the use of information technology has positive influence on the quality of reporting of regional assets. Based on the concepts and empirical evidence obtained from previous research, hypotheses 3 is proposed:

H3 : Information technology had positive effects on asset management.

\section{The Relationship of Intensity of Reconciliation With Asset Management}

Reconciliation is one key in efforts to create credible financial statements, in line with these two before the present value of assets in the financial statements to be reconciled in advance either at the internal level the working unit with DPPAD, the working unit with the bureau of finance and DPPAD with the Finance Bureau. With the reconciliation, it can produce accurate data and asset management goes well . 
Grubisic (2009) stated that the intensity of reconciliation affects the quality of financial reporting. Based on the concept and empirical evidence obtained from previous studies, the hypothesis 4 is proposed:

H4 : Intensity reconciliation had positive effects on asset management.

\section{The Relationships of Internal Control Systems ( SPI ) With Asset Management}

Internal control is a way to direct, monitor, and measure the resources of an organization, as well as plays an important role in the prevention and detection evasion (fraud). Internal control consists of policies and procedures used in achieving the goals and guarantee or providing reliable financial information, and ensuring compliance with applicable laws and regulations .

Pradono (2014), in his research on "Quality of Local Government Finance Report, Factors Influencing and Policy Implications (Case Study on the Working Unit of the Central Java Provincial Government)", found a significant effect of the internal control system with the quality of financial reporting. Based on these descriptions, Hypothesis 5 is proposed:

H5: Internal control system had positive effects on asset management.

\section{Research Methods}

The population of this research was the manager and/or storage of goods and compilers of financial statements the working unit of Central Java Provincial Government. Target population in this study was an officer/staff directly involved technically in asset management and preparation of financial reporting. The sample was caretaker goods, head of public, and accounting staff preparation of financial statements. The number of samples of each the working unit are 3 (three) so that the number of respondents is 144.

\section{Data Collection Methods}

Data were collected through questionnaires that were delivered and taken by researcher directly to some respondents administrators of goods and compilers of financial statements at the working unit. The questionnaires were used to obtain data on the competence of human resources, regulation, information technology, the intensity of reconciliation, and internal control systems.

Data were then analyzed by multiple linear regression method to determine the influence of the competence of human resources (HR), the regulation (LAW), the information technology (TIF), the intensity of reconciliation (RKN), and the internal control system (SPI) to the asset management (MA). The regression equation in this study was:

$$
\mathrm{MA}=\beta_{1} \mathrm{SDM}+\beta_{2} \mathrm{LAW}+\beta_{3} \mathrm{TIF}+\beta_{4} \mathrm{RKN}+\beta_{5} \mathrm{SPI}+€
$$

\section{Results and Discussion}

Total of 144 questionnaires were distributed and all have been returned. Validity test of the data was done using factor analysis in which an indicator was valid if it had KMO value of more than 0.5 and the loading factor above 0.4. Based on the validity of the test results, the indicators in the variable MA were invalid because it had a loading factor of 0.383 , so that only 20 indicators were included into the next test phase, while in the variable HR, LAW, TIF, RKN, and SPI, all indicators were valid.

From the results of reliability test, Cronbach Alpha value for each variable was MA (0.914), HR (0.908), LAW (0.773), TIF (0.891), RKN (0.928), and SPI (0.894). Because the value of Cronbach Alpha for all the variables was more than 0.6 , it could be concluded that the questionnaire used as a measuring tool used in this 
study was feasible. Based on tests of normality, it appears that the regression model fullfilled normallity asumption. By using the Kolmogorov-Smirnov, it showed the level of significance of the study variables is 0.530 .

Then based on Table 1, the multiple regression equation is obtained as follows:

$$
\begin{aligned}
& \mathrm{MA}=0.166 \mathrm{SDM}+0.161 \mathrm{LAW}+0.349 \mathrm{TIF}+0.127 \mathrm{RKN}+0.186 \mathrm{SPI} \\
& \mathrm{Sig.}(0.017)+(0.026)+(0.000)+(0.046)+(0.010)
\end{aligned}
$$

Table 1

Research Output

\begin{tabular}{lllll}
\hline Variables & Coeff. & $\mathrm{t}$ & Sig. & VIF \\
\hline SDM & 0.166 & 2.424 & 0.017 & 2.082 \\
LAW & 0.161 & 2.254 & 0.026 & 2.256 \\
TIF & 0.349 & 4.816 & 0.000 & 2.324 \\
RKN & 0.127 & 2.017 & 0.046 & 1.765 \\
SPI & 0.186 & 2.602 & 0.010 & 2.257 \\
\hline & R $=0.830$ & & \\
& Adj.R Square $=0.667$ & & \\
& DW $=1.839$ & & \\
\hline
\end{tabular}

Source: SPSS Research Output (2016).

\section{Hypothesis Testing}

Partial hypothesis testing was performed by $t$ test by comparing the calculation results with a significance value of 0.05 (rule of thumb).

(a) hypothesis 1

From Table 1 we could see that $t$ value of HR was equal to 2.424 with a significance of $0.017(<0.05)$. Therefore, it was proven statistically that HR had a positive and significant impact on MA. Thus, the first hypothesis which states that "The competence of human resources had positive influence on asset management" was accepted.

(b) hypothesis 2

From Table 1 we could see that $t$ value of LAW is equal to 2.254 with a significance of $0.026(<0.05)$. Therefore, it was proven statistically that the LAW had a positive and significant impact on MA. Thus, the second hypothesis which states that "Regulation positively influences asset management" was accepted.

(c) hypothesis 3

From Table 1 we could see that $t$ value of TIF was equal to 4.816 with a significance of $0.000(<0.05)$. Therefore, it was proven statistically that the TIF had a positive and significant impact on MA. Thus, the third hypothesis which states that "Iformation technology has positive influence on asset management" was accepted.

(d) hypothesis 4

From Table 1 we could see that $t$ value of RKN was equal to 2.017 with a significance of $0.046(<0.05)$. Therefore, it was proven statistically that RKN had a positive and significant impact on MA. Thus hypothesis 4 which states that "The intensity reconciliation positively influences asset management" was accepted.

(e) hypothesis 5

From Table 1 we could see that $t$ value of SPI was equal to 2.602 with a significance of $0.010(<0.05)$. 
Therefore, it is proven statistically that the SPI had a positive and significant impact on MA. Thus hypothesis 5 which states that "The internal control system has positive influence on asset management" was accepted.

\section{Discussion}

The results of this study proved that the competence of human resource, regulation, information technology used, the intensity of Reconciliation, and the Internal Control System were significant factors in the implementation of asset management at the working unit of Central Java Provincial Government.

Human resource is one of the very important elements of the organization, therefore, it must be ensured that the management of human resources is done as possible in order to contribute optimally to the achievement of organizational goals. In governance, particularly in asset management, intellectual ability and physical ability are needed by government officials to secure and optimize their assets. Based on this study, it appears that human resources related to the implementation of asset administration at the working unit mostly have adequate educational competence and have sufficient working time to be able to perform the task well. Nevertheless, some of the working unit still lacks human resources accounting education background that has the task in the presentation of the value of assets on the balance sheet, thus affecting the quality of the reporting of the value of assets.

Regulation is a provision which is used to regulate human relationships in a society or a country. Regulation on local asset management is an instrument of policy and guidelines for asset management area, so it is a basic reference for asset management and implementation in the working unit.

Regulation of the Central Java Governor Number 96 of Year 2012 on Guidelines for Management of Regional and regulations of the Central Java Governor Number 45 of Year 2014 concerning Policy and Accounting System of Central Java Province are used as a reference implementation of the administration, management, recognition, measurement, and presentation of assets on the balance sheet. Both the Governor Regulations are interconnected and not against making it easier for implementers in the implementation of asset management at the working unit.

Utilization of information technology greatly helps speed up data processing transactions and presentation of financial statements and government assets so that the financial statements and the assets of the area do not lose the value of the information that is timeliness. SIM Application Assets Central Java Provincial Government made easily implemented by the managers at the working unit and output from these applications easily obtained at any time because it has been done online.

Reconciliation in Central Java Provincial Government is based on the Central Java Governor Regulation No. 68 of Year 2012 on Standards and Operating Procedures Fiscal Management Central Java Province. Reconciliation with internal and external working unit can identify errors in early presentation of the reporting of assets and minimize the occurrence of correction.

Although the intensity of reconciliation has positive effect on asset management, in reality, there are many working units that are reluctant to perform internal reconciliation. Reconciliation between the board and the items making up the financial statements is done now, which is facilitated by DPPAD as an asset manager in Central Java Provincial Government and the Finance Bureau as a constituent of the financial statements. The working unit has to reconcile before DPPAD and Finance Bureau, so that misstatements presentation and correction can be minimized.

Internal control system of the working unit among other things manage: clearing tasks and responsibilities distribution, implementing mechanisms of reward and punishment, as well as determining the policies and 
standard operating procedures in the management of local goods. With the existence of an adequate system of internal control, making the working unit can provide a reliable local goods report for each level of management/leadership as basis for performance evaluation and decision making. More detail, policies, and procedures that are used directly for the purpose of achieving the target in the presentation of the value of assets in the financial statements of the working unit are accurate and ensure observance or compliance with laws and regulations. Although most of the working unit had own rules and regulations about Internal control system, some of the working unit do not have it. Less than optimal implementation of internal control system is the cause of the emergence of the problem assets on LHP of the audit board of the Republic Indonesia on the examination of financial statements.

\section{Policy Implications}

Asset management has an important role for the government because it is an integral part of an organization's financial management. Local Government as an organization must conduct the management of state property professionally, effectively, and economically. It is necessary for the expenditure of the costs to be appropriately targeted, appropriately used, and appropriately implemented in accordance with applicable provisions.

Good governance of local government property will certainly facilitate the inventory of local assets. It then becomes an important resource for local governments to support various efforts to increase local revenue. Therefore, it is important for local governments to be able to manage assets adequately and accurately. On the basis of its importance, the implementation of asset management in Central Java Provincial Government needs to get special attention, especially related to the problem of assets that still appears in the Report of Inspection Result by the State Audit Board.

The working unit of the Central Java Provincial Government must immediately improve the quality of its asset management by addressing the constraints and shortcomings during this case. The focus of attention of the manager/leader on improving the quality of asset management are the competence of human resources, the intensity of reconciliation, and internal control systems. It is because these three factors will determine the implementation of good asset management. The evidence suggests that the competence of human resources, the intensity of reconciliation, and internal control systems within the scope of asset management sectors in the Central Java Provincial Government remain inadequate.

The policy that can be done is the structuring of human resources based on the concept of the right man on the right job. Position analysis needs to be done to determine the requirements that are suitable for human resources who will perform the task at a certain position. Through proper human resource management policy, asset management in SKPD will be filled by the right people based on knowledge and skill according to job description in that section. Structuring of the staff of goods in SKPD in Central Java can be started by replacing the old steward with the younger staff and having sufficient education. In addition it is necessary to rotate and disseminate human resources background accounting education to be able to perform tasks as staff compilers of financial statements. The unequal distribution of uneducated accounting human resources will result in reduced quality of asset value representation on the balance sheet.

The development of human resource competencies to the local government can also adopt what has been done by some private agencies/state, where the newly hired employee who first provided education/training/briefing as a basis for future work. What is happening until now is that new employees are 
not getting enough stock of knowledge and lack of opportunities for continuing education/training appropriate to the tasks/fields of operation.

The amount of coverage in the region of Central Java Provincial Government requires good coordination between administrators of goods in the working unit mains and auxiliary board stuff in integrated services unit of the working unit. This requires internal reconciliation of the working unit. In addition to internal reconciliation on education, it is necessary to establish an external policy of reconciliation between the working unit with Central Government and District/City Government related to assets cooperated and assets donated. This is useful for asset security and clarity area utilization so as to contribute to the acceptance of local revenues. With the clarity of the status of ownership of assets and the amount of value, it is expected that these problems will no longer appear on the audit report of the audit board of the Republic Indonesia.

The element that is no less important is the optimization of the implementation of the internal control system. There are still the working unit, not yet have rules/policy/technical instructions on asset management internally, whereas that the working unit with rules/policy/technical instructions on asset management internally has not been optimally implemented. Optimizing the SPI implementation is important because research shows that the internal control system has a dominant role in asset management of the working unit.

It is necessary to evaluate the effective delegation of tasks related to the management of assets. In the delegation of tasks, users goods in this case, the head of the working unit needs to be really selective in choosing asset management executive staff. Another thing that needs to be done in improving Internal Control System is to conduct an inventory in an orderly manner to the assets owned by providing clear and detailed information on Inventory Item Cards

\section{Conclusion}

After testing and analysing data in this study, overall, it can be concluded in accordance with the hypothesis that has been formulated that competence of human resource, regulation, information technology, intensity reconciliation, and internal control systems has positive and significant impact on asset management.

\section{Recommendations}

Based on the findings of this study, the following policy recommendations are given:

(1) Placing employees in accordance with the specifications and competence education and providing education/training/technical assistance/courses on asset management for employees/staff regularly and periodically to improve the quality of human resources in the asset manager of the working unit.

(2) Improving the understanding of the existing regulations related to the management of local goods and financial management with an update on regulations change frequently.

(3) Maximizing the use of information technology by improving the ability of employees in using information technology and regularly updating the software and hardware on the use of information technology.

\section{References}

Abdullah, S., Razak, A. A., \& Pakir, A. H. K. (2011). The characteristics of real estate assets management practice in the Malaysian Federal Government. Journal of Corporate Real Estate, 13(1), 16-35.

Azhar. (2007). Faktor-Faktor Yang Mempengaruhi Keberhasilan Penerapan Permendagri Nomor 13 Tahun 2006 Pada Pemerintah Banda Aceh. Tesis Universitas Sumatera Utara, Medan. 
Azhar, I., \& Darwanis, S. A. (2013). Pengaruh Kualitas Sumber Daya Manusia, Regulasi, dan Sistem Informasi Terhadap Manajemen Aset Daerah (Studi pada SKPD Pemerintah Kota Banda Aceh). Jurnal Akuntansi Pasca Sarjana Universitas Syah Kuala, 2. 15-26.

Darno. (2012). Analisis Pengaruh Kemampuan Sumber Daya Manusia dan Pemanfaatan Teknologi Informasi terhadap Kualitas Laporan Barang Kuasa Pengguna (Studi pada Satker di Wilayah Kerja KPPN Malang). Jurnal Ilmiah Mahasiswa FEB Universitas Brawijaya Malang, 1(1).

Goodhue, D. L., \& Thompson, R. L. (1995). Task-technology fit and individual performance. MIS Quarterky, 213-236.

Grubisic, N. M. (2009). Toward efficient public sector asset management. Disertasi, Zagreb: The Institue of Economics.

Hanis, H. M., Trigunarsyah, B., \& Susilawati, C. (2011). The application of public asset management in Indonesian local government: A case study in South Sulawesi province. Journal of Corporate Real Estate, 13(1), 36-47.

Haryanto, H. (2013). Pengelolaan dan Akuntansi Keuangan Daerah. Semarang: Undip Press.

Liu, J. Y. (2000). Fiscal decentralization and economic growth in China. Economic Development and Cultural Change, Chicago, $49,1-12$.

Oates, W. E. (1995). Comment on "conflict and dillemas of decentralization" by Rudolf Holmes. The World Bank Research Observer, 351-355.

Pradono, F. C. (2014). Kualitas Laporan Keuangan Pemerintah Daerah Faktor yang Mempengaruhi dan Implikasi Kebijakan (Studi Kasus pada SKPD Pemerintah Provinsi Jawa Tengah). Tesis: Program Pasca Sarjana Universitas Stikubank. Semarang.

Von Hagen, J. (2002). Fiscal rules, fiscal institutions and fiscal perfomance. The Economic and Social Review, 33(3), $263-284$.

Wong, J. D. (2004). The fiscal impact of economic growth and development on local government capacity. Journal of Public Budgeting, Accounting and Financial Management. Fall, 16(3), 799-816. 